\title{
THE
}

\section{Mental accounting and behavioural hierarchy: Understanding consumer budgeting behaviour}

Jing Jian Xiao

University of Rhode Island, jjxiao@uri.edu

Barbara O'Neill

Follow this and additional works at: https://digitalcommons.uri.edu/hdf_facpubs

The University of Rhode Island Faculty have made this article openly available.

Please let us know how Open Access to this research benefits you.

This is a pre-publication author manuscript of the final, published article.

Terms of Use

This article is made available under the terms and conditions applicable towards Open Access Policy Articles, as set forth in our Terms of Use.

\section{Citation/Publisher Attribution}

Xiao JJ, O'Neill B. Mental accounting and behavioural hierarchy: Understanding consumer budgeting behaviour. Int J Consum Stud. 2018;42:448-459. https://doi.org/10.1111/ijcs.12445

Available at: https://doi.org/10.1111/ijcs.12445

This Article is brought to you for free and open access by the Human Development and Family Science at DigitalCommons@URI. It has been accepted for inclusion in Human Development and Family Science Faculty Publications by an authorized administrator of DigitalCommons@URI. For more information, please contact digitalcommons-group@uri.edu. 


\title{
MENTAL ACCOUNTING AND BEHAVIORAL HIERARCHY: UNDERSTANDING CONSUMER BUDGETING BEHAVIOR
}

\begin{abstract}
Budgeting is an important step in consumer finance. Budgeting behavior is considered a desirable financial behavior to indicate consumer financial capability. However, systematic research on budgeting behavior with a large scale national sample is limited. The purpose of this study was to address this research gap and examine characteristics of budgeting behavior from the perspective of a behavioral hierarchy, which is related to mental accounting. The assumption holds that consumer financial behaviors may be performed in a hierarchical manner along with an increase in economic resources. Using data from the 2015 National Financial Capability Study, evidence suggests that budgeting behavior is at the lower end of the behavioral hierarchy. This finding has implications for consumer financial educators.
\end{abstract}

\section{Introduction}

Inspired by the theory of mental accounting (Thaler, 1985), this study examined the characteristics of consumer budgeting behavior. Mental accounting refers to "the set of cognitive operations used by individuals and households to organize, evaluate, and keep track of financial activities" (Thaler, 1999, p.183). According to Thaler, mental accounting includes several components. One of the components of mental accounting concerns the frequency with which accounts are evaluated. Accounts can be balanced daily, weekly, yearly, and so on, and can be defined narrowly or broadly. We argue that this characteristic of mental accounting can be reflected in consumer financial behaviors, for example, budgeting behavior. Specifically, we assume that consumer budgeting behavior is located at the low end of behavioral hierarchy. 
Research shows that budgeting behavior is common when it is broadly defined among consumers (Bankrate, Inc., 2015) and is related to other desirable financial behaviors (O’Neill, Xiao, \& Ensle, 2017). Previous research examined budgeting behaviors from perspectives of first home buying and life cycle stages (Davis \& Carr, 1992; Mullis \& Schnittgrund, 1982; Shelton \& Hill, 1995) and reference budgets (Preuße, 2012). Unlike previous research, this study examined budgeting behavior from a unique perspective of behavioral hierarchy using a large sample of American consumers. The study had four objectives, 1) to provide a profile of consumers who perform budgeting behavior, 2) to examine how budgeting behavior is associated with financial capability variables, 3) to explore the status of budgeting behavior in the behavioral hierarchy, and 4) to examine how budgeting behavior is associated with consumer financial well-being.

\section{Previous Research}

Studies have shown that people who prepare a detailed household financial budget are in the minority among U.S. residents (Jacobe, 2013; Davis \& Carr, 1992). Despite urging by financial experts to develop a budget to allocate future income and expenses, recent studies have found that less than half of all Americans actually do. Hogarth, Hilgert, and Schuchardt (2002) reported results from a national survey about the financial management practices of U.S. households. Less than half (46\%) of 1,004 respondents used a budget and only $36 \%$ planned and set goals for the future. O'Neill and Xiao (2012) investigated the performance of 20 financial management practices using an online financial self-assessment tool with 10,661 respondents from 2005 through 2010. Budgeting was among five quiz items that were least frequently performed, ranking 16 out of 20 , in order of mean scores.

A widely quoted Gallup Economy and Personal Finance Survey (Jacobe, 2013) found that only $32 \%$ of American households prepare a written budget or use software to develop one. 
Davis and Carr (1992) also found that only a minority of households had written budgets. In addition, respondents in the retirement age stage of the lifecycle were least likely, compared to younger households, to have any kind of budget and least likely to have a written budget. When budgeting is described in less rigid and time-intensive terms (i.e., without having to be on written down on paper or in a computer spreadsheet), more Americans say that they do it. For example, a survey by Bankrate Inc. (2015) found that $82 \%$ of Americans kept a household budget. However, only $36 \%$ of those surveyed used a pen and paper while $18 \%$ kept information in their heads and $26 \%$ used a computer program or smart phone application.

The Consumer Financial Protection Bureau (2017) conducted research to help consumers deal with spending challenges and found that over $90 \%$ of consumers were interested in using a tool or mobile application to provide information on their spending and account balances in as close to real time as possible. In other words, how much money would be left in their budget if they made a purchase? The process of budgeting has its benefits. O'Neill, Xiao, and Ensle (2017) reported findings of multivariate analyses that indicated positive and statistically significant relationships between the practice of using a budget and eighteen positive health and financial practices. Specifically, their results suggested that consumers who reported following a budget scored higher in both health and financial practice indexes. A study of a program for first-time homebuyers found that exposing participants to budgeting principles could be a factor in helping consumers become successful homeowners (Shelton \& Hill, 1995). DeHart, Friedel, Lown, and Odum (2016) found evidence that students taking a financial education course exhibited less impulsive behavior and more self-control than those who didn't with respect to delay discounting; i.e., a choice between smaller, immediate outcomes and larger, delayed outcomes. For the counseling purpose, Preuße (2012) developed reference budgets for German consumers. 
Several studies have also raised questions about the emphasis that financial educators and advisors place upon budgeting. Davis and Carr (1992) noted that it may be a mistake to assume that retirement-aged clients who do not have budgets need them. Perhaps they have developed stable and predictable patterns of income and spending and thus perceive no need for a budget, which requires time to gather and analyze income and spending information. Mullis and Schnittgrund (1982) studied the use of budgeting, the style of budgeting used, budgeting and non-budgeting household's satisfaction with income, and attitudes toward money management practices. Their conclusions showed that families who budget were no more satisfied with their incomes than those who did not budget.

\section{The Perspective of Behavioral Hierarchy and Hypotheses}

\section{The Assumption of Behavioral Hierarchy}

The human needs hierarchy was first proposed by Maslow (1954). Later, several economic theories acknowledged the hierarchy of economic behaviors. For example, based on several advances in psychology including mental accounting, the behavioral lifecycle hypothesis assumes that consumer propensities for consumption are decreasing based on asset types (Shefrin $\&$ Thaler, 1988). The new consumer demand theory asserts that consumer preferences change alone with their income (Lancaster 1991). The hierarchical patterns of consumer financial behaviors are also documented in empirical studies such as saving motives (Canova, Rattazzi, \& Webley, 2005; DeVaney, Anong, \& Whirl, 2007; Lee \& Hanna, 2015; Xiao \& Noring, 1994) and saving behavior (Hilgert, Hogarth, \& Beverly, 2003; Xiao \& Olson, 1993; Xiao \& Anderson, 1997). Consumer financial behaviors may be categorized in a hierarchical manner (Xiao, 2016). Based on these theories and empirical studies, a behavioral hierarchy assumption is proposed that 
consumer financial behaviors can be categorized along with economic resources. When the level of economic resources is low, consumers are more likely to perform a certain set of behaviors. When the level of economic resources is higher, consumer are more likely to perform another set of behaviors. Budgeting behavior is assumed to be at the low end of the behavioral hierarchy.

\section{Budgeting and Economic Resources}

Budgeting may be more important for consumers with limited resources. If a consumer's income is higher than a certain level, he or she may not worry about budgeting as much because income is ample to cover projected expenses. Previous research shows that consumers with a written budget are in minority (Bankrate, 2015; Davis \& Carr, 1992) and having budgeting is not related to financial satisfaction (Mullis \& Schnittgrund, 1982). Based on this reasoning and empirical evidence, the following hypothesis is proposed:

H1: Budgeting behavior is negatively associated with economic resources.

\section{Budgeting and Financial Capability}

Financial capability can be defined broadly to include financial knowledge, resource, access, and habits (Lin et al. 2016). In the research literature, financial capability and financial literacy are often used interchangeably. For example, some researchers focus on financial literacy and define financial literacy as “people’s ability to process economic information and make informed decisions about financial planning, wealth accumulation, debt, and pensions" (Lusardi \& Mitchell, 2014, p.6). Other researchers define financial capability based on financial behavior measures (Atkinson et al., 2006). Financial capability is also considered to include access to financial resources for low income populations (Birkenmaier, Sherraden, \& Curley, 2013). In this study, financial capability is defined as a skillful combination of financial 
knowledge and behavior, i.e., an ability to apply appropriate financial knowledge and perform desirable financial behavior to achieve financial wellbeing (Xiao, Chen, \& Chen, 2014; Xiao \& O’Neill, 2016).

If budgeting is an indicator of financial capability, it should be correlated with other financial capability variables such as financial literacy and other financial behaviors. Previous research shows that financial literacy correlated with positive financial behaviors such as stock participation (Chu, Wang, Xiao, \& Zhang, 2016; Van Rooij, Lusardi, \& Alessie, 2011) and budgeting behavior is positively associated with other desirable financial behaviors (O'Neill at al., 2017). Thus, the following hypothesis is proposed:

H2: Budgeting behavior is positively associated with financial capability variables.

\section{Budgeting in the Financial Behavioral Hierarchy}

The assumption of behavioral hierarchy holds that, when economic resources increase, consumers perform different behaviors to meet their new needs, which are shown in previous research (see the subsection of this section). Budgeting is a basic step in financial planning and counseling that should be considered at the low end of the behavioral hierarchy. Some evidence supports this notion. In the 2015 National Financial Capability Study, the proportion of respondents holding a budget varied little across income levels (54-57\%) while proportions of respondents who have long term plans were positively associated with income levels, from $41 \%$ of the low income group to $70 \%$ of the high income group (Lin et al. 2016). The following hypothesis is proposed:

H3: Budgeting behavior is at the low end of the behavioral hierarchy. 


\section{Budgeting and Financial Well-being}

Previous research indicates that financial capability variables are positively associated with financial well-being (Xiao et al. 2014; Xiao \& O’Neill 2016). If budgeting behavior is an indicator of financial capability and correlated with other financial capability variables, it should be contributing to financial well-being. Thus the following hypothesis is proposed:

H4: Budgeting behavior is positively associated with financial well-being.

\section{Method}

\section{Data}

Data used in this study were from the 2015 U. S. National Financial Capability Study, commissioned by the FINRA Investor Education Foundation and conducted by Applied Research and Consulting LLC, which included 27,564 American adults (roughly 500 per state and the District of Columbia). Descriptive statistics and other background information about this data set can be found in Lin et al. (2016). The NFCS is a triennial survey, started in 2009, that has been widely used and validated as a representative sample of the American population by researchers in economics, business, consumer science, and other social science fields. In the 2015 survey, budgeting is one of the new questions asked.

\section{Variables}

Table 1 presents detailed information about variables used in this study. Budgeting behavior is the focus of this study. In the NFCS survey, budgeting behavior is asked in a question "Does your household have a budget?" In this study, the variable was measured by a binary variable with $1=$ having a budget and $0=$ other. Four other financial behavior binary 
variables were used to indicate if a respondent performed the following behaviors:

underspending, saving for an emergency, long-term planning, and calculating retirement needs. These behavioral variables are considered indicators of financial capability.

Following previous research (Xiao \& O'Neill, 2016), besides desirable financial behaviors, other financial capability variables include objective financial literacy, subjective financial literacy, and perceived financial capability. Objective financial literacy is the quiz score of six financial knowledge questions ranging from 0 to 6 . Subjective financial literacy is a self-assessment of financial knowledge with a range of 1-7 (1=very low, 7=very high). Perceived financial capability is a self-assessment of money management ability with a range of 1-7 (1=very low, 7=very high). Financial well-being is composed of household income and financial satisfaction. Since two variables have different metrics, a sum of Z-scores of the two variables is used for the variable. Several demographic and financial variables are also included in the analyses.

\section{Data Analyses}

Both bivariate and multivariate analyses were conducted to test the hypotheses. Specifically, Chi-square tests and logistic regression were used to test H1. Chi-square tests were used to test the correlations between budgeting behavior and other financial capability and financial behavior variables for testing $\mathrm{H} 2$ and $\mathrm{H} 3$. Chi-square tests and OLS regressions were used to test H4. All analyses were conducted using SPSS software. 


\section{Results}

\section{Profile of Budgeters}

Budgeters refer to respondents who reported having a budget in the survey. Table 2 presents the results of Chi-square tests showing profiles of budgeters. Among the total sample, $56.2 \%$ reported that they had a budget. Regarding demographic factors, respondents who were female, nonwhite, married, having dependent children, working, younger, or with higher education were more likely to be a budgeter. The pattern of household income was a reverse $\mathrm{U}$ shape with the middle income group most likely to be a budgeter. Regarding financial product holdings, respondents who had checking, saving, 401(k) type account, and IRA accounts were more likely to be a budgeter. Respondents who owned a home, had credit card, or had health insurance were more likely to be a budgeter. Interestingly, respondents who owe all types of debt (i.e., mortgage, home equity, auto loan, unpaid medical bills, credit card debt, student loan, and high cost loan) were also more likely to be a budgeter.

Table 3 presents results of the logistic regression on being a budgeter when all demographic and financial factors were included in the model. The results are similar to those of the Chi-square tests with several changes. First, four variables' effects disappeared: having a home, auto loan, unpaid medical bill, or student loan. Second, two variables' effects in Chisquare tests changed. Home owning's effect changed from a positive one to a negative one. Income's effect changed from a reverse U shape to a negative one. For budgeting behavior, when all factors were included in one logit model, respondents with a higher income were less likely to perform budgeting behavior. This finding supports H1 (Budgeting behavior is negatively associated with economic resources). 


\section{Budgeting and Financial Capability Variables}

Figure 1 presents results of Chi-square tests on several financial capability variables by budgeting behavior. All the Chi-square test results are significant (statistics are not shown but are available upon request). Two patterns are shown. For subjective financial literacy and perceived financial behavior, respondents rated higher in the two variables (6 or 7 on a 7 -point scale) were more likely to perform budgeting behavior. The second pattern was shown in objective financial literacy, where respondents who scored in the low to middle range (2-4 on a 6-point scale) were more likely to perform budget behavior.

Figure 2 presents results of Chi-square tests on several financial behaviors by budgeting behavior. All Chi-square tests results were significant (statistics are not shown but are available upon request). The results show that desirable financial behaviors were positively associated with budgeting behavior, implying that budgeting behavior is also a desirable behavior. These findings provided strong evidence to support $\mathrm{H} 2$ (Budgeting behavior is positively associated with financial capability variables).

\section{Budgeting Behavior in the Behavioral Hierarchy}

To test $\mathrm{H} 3$, planning was selected as a behavior at the high end of the behavioral hierarchy. Planning behavior is associated with high economic status and financial capability variables, and contributing to financial well-being (Xiao \& O'Neill, 2017). Figures were constructed to compare budgeting and planning behavior by financial resource variables. In Figure 3, it is interesting to see that, for two variables measuring financial well-being, household income and financial satisfaction, they show different patterns. The proportions of budgeters across income or financial satisfaction categories are very similar, but proportions of planners 
across the two financial well-being variables' categories are positively correlated. In other words, the proportions of budgeters in all financial well-being categories are similar but planners are more likely to be found in higher financial well-being categories. The patterns support H3 (Budgeting behavior is at the low end of the behavioral hierarchy).

\section{Budgeting and Financial Well-being}

Figure 4 shows Chi-square results on two financial well-being variables by budgeting behavior and two patterns are shown. The results were statistically significant (relevant statistics are now shown but available upon requests). For income, only income levels in several middle categories (from $\$ 15,000$ to $\$ 100,000$ ) were more likely than lower or higher counterparts to be a budgeter. However, financial satisfaction is positively associated with being a budgeter. On a 10point scale, respondents rated 5 or higher are more likely to perform budgeting behavior.

Table 4 presents results of OLS regressions. The results show that the coefficient estimate of budgeting has a positive sign when only the budgeting variable was regressed with the financial well-being variable. When other financial capability variables were entered the model (model 2) or demographic and financial variables were entered the model (model 3), the coefficient of budgeting became negative. These findings do not support H4 (Budgeting behavior is positively associated with financial well-being). Further exploration showed that when other financial behavior variables were entered the model, budgeting's sign changed to negative. It suggests that if other desirable financial behaviors are performed, budgeting may reduce financial well-being. The possible explanation is that budgeting is a basic financial management behavior. If no other behaviors are performed, budgeting may contribute to financial well-being. If other desirable financial behaviors are performed, budgeting may indicate a low economic 
status that shows a negative association with financial well-being, confirming $\mathrm{H} 3$ again that budgeting is at the low end of the behavioral hierarchy.

Additional analyses among income subgroups were conducted (results are not shown but are available upon request) and the results do not support H4 but do support H3. Among lowincome groups, budgeting behavior showed a positive effect after other financial behavior variables were entered to the model. However, among middle- and high-income subgroups, the effects of budgeting behavior changed to a negative one when other financial behavior variables were entered to the model. The results suggest that budgeting is a basic financial behavior and is especially important for low-income consumers. When consumers have more income, other financial behaviors become more important. This may also imply that higher order behaviors need budgeting as a prerequisite. For example, to do long-term planning, budgeting is a basic step to earmark savings required to achieve financial goals.

\section{Discussion}

This study tested a behavioral hierarchy assumption where consumer financial behaviors can be categorized in a hierarchical manner along with economic resources. The results suggested that budgeting behavior is negatively associated with economic resources, desirable financial behaviors are positively associated with budgeting behavior, and budgeting behavior is at the low end of the behavioral hierarchy. Budgeting behavior is more important for low-income consumers to achieve financial well-being.

It appears that benefits of budgeting vary according to consumer characteristics and that budgets are especially helpful for those with limited resources. This result supports the findings of Davis and Carr (1992), who noted that it may be a mistake to assume that everyone who does 
not have a budget needs one, especially older consumers. The benefits of budgeting for enhancing financial capability found in this study are also in line with prior research (Shelton \& Hill, 1995; O’Neill, Xiao, \& Ensle, 2017).

Limitations of this study include the simplified measure of budgeting behavior and selfreported behavior. In the survey, only one question is asked about budgeting behavior. More details about budgeting format, purposes, and patterns are not available. Also, budgeting and other financial behaviors are self-reported that may have validity and accuracy problems. The actually observed behaviors may provide more accurate information regarding consumer financial behavior. These issues may be addressed in future research.

Keeping the limitations in mind, findings of this study have following implications for consumer service professionals:

Encourage low-income consumers to budget. The findings suggest that among lowincome consumers, budgeting behavior contributes to financial well-being. This finding is understandable because this subsample presumably lacks economic resources such as an adequate income and emergency savings reserve and, thus, have few or any economic "buffers" to make ends meet. Thus, they must track every penny of income and stretch it as far as possible. Budgeting requires time and advance planning, however. Perhaps the budgeting process can be broken down into simpler steps that do not necessitate the time-intensive tracking of every purchase for a defined period of time. Budgeting phone apps might also encourage this practice.

Reframe budgeting. This study showed that budgeting has positive effects on financial capability. People often know that they should budget, but may not want to or know how. Perhaps they need procedural knowledge (i.e., what to do and how to do it). If the issue is, 
instead, related to motivation (e.g., time constraints and/or perceived "deprivation" as a result of budgeting) reframe budgeting a small spending restrictions today to insure a better future tomorrow. Planners and counselors could illustrate the benefits of budgeting with tools that provide personalized spending analyses to help people understand the impact of their daily spending habits on their "future self."

Continue exploring behavioral hierarchy practices. This study supported the assumption that consumer financial behavior may be performed in a hierarchical manner and can be categorized on a continuum of increasing economic resources. This study specifically explored the practice of budgeting and found that respondents with a higher income were less likely to perform this behavior. Additional research about hierarchical financial behavior should be conducted with other aspects of financial planning including saving and investing, banking and borrowing, the purchase of insurance, and retirement planning. 


\section{References}

Atkinson, A., McKay, S., Collard, S. \& Kempson, E. (2006). Levels of financial capability in the UK: Results of a baseline survey. Financial Services Authority, London.

Bankrate, Inc. (2015, January). 3 in 5 Americans don't have enough savings to pay for unexpected expenses. New York, NY: Author.

Birkenmaier, J., Sherraden, M., \& Curley, J. (Eds.). (2013). Financial capability and asset development: Research, education, policy, and practice ( $\left.1^{\text {st }} \mathrm{ed}.\right)$. New York: Oxford University Press.

Canova, L., Rattazzi, A. M. M., \& Webley, P. (2005). The hierarchical structure of saving motives. Journal of Economic Psychology, 26(February), 21-34.

Chu, Z., Wang, Z., Xiao, J. J., \& Zhang, W. (2016). Financial literacy, portfolio choice and financial well-being. Social Indicators Research, 132(2), 799-820.

Consumer Financial Protection Bureau (2017). Consumer insights on managing spending. Washington, DC: Consumer Financial Protection Bureau.

Davis, E. P., \& Carr, R. A. (1992). Budgeting practices over the life cycle. Financial Counseling and Planning, 3, 3-16.

DeHart, W.B., Friedel, J.E., Lown, J.M., \& Odum, A. L. (2016). The effects of financial education on impulsive decision-making. PLOS. Retrieved from http://journals.plos.org/plosone/article?id=10.1371/journal.pone.0159561.

DeVaney, S. A., Anong, S. T., \& Whirl, S. E. (2007). Household savings motives. Journal of Consumer Affairs, 41(Summer), 174-86.

Hilgert, M. A., Hogarth, J. M., \& Beverly, S. G. (2003, July). Household financial management: The connection between knowledge and behavior. Federal Reserve Bulletin, 89, 309-322. 
Hogarth, J.M., Hilgert, M.A., \& Schuchardt, J. (2002). Money managers: The good, the bad, and the lost. In J.M. Lown (Ed.), Proceedings of the Association for Financial Counseling and Planning Education, 12-23.

Jacobe, D. (2013). One in three Americans prepare a detailed household budget. Gallup Economy and Personal Finance Survey. Retrieved from http://www.gallup.com/poll/162872/one-three-americans-prepare-detailed-householdbudget.aspx.

Lancaster, K. J. (1991). Modern consumer theory. Worcester: Billing \& Sons.

Lee, J. M., \& Hanna, S. D. (2015). Savings goals and saving behavior from a perspective of Maslow's hierarchy of needs. Journal of Financial Counseling and Planning, 26(2), 129147.

Lin, J. T. Bumcrot, C., Ulicny, T., Lusardi, A., Mottola, G., Kieffer, C., \& Walsh, G. (2016). Financial capability in the United States 2016. Washington, DC: FINRA Investor Education Foundation.

Lusardi, A., \& Mitchell, O. S. (2014). The economic importance of financial literacy: Theory and evidence. Journal of Economic Literature, 52(1), 5-44.

Maslow, A. H. (1954). Motivation and personality. New York: Harper and Brothers.

Mullis, R. J., \& Schnittgrund, K. P. (1982). Budget behaviour: Variance over the life cycle of low income families. International Journal of Consumer Studies, 6(2), 113-119.

O’Neill, B. \& Xiao, J.J. (2012). Financial behaviors before and after the financial crisis: Evidence from an online survey. Journal of Financial Counseling and Planning, 23 (1), 33- 46.

O’Neill, B., Xiao, J.J., \& Ensle, K. (2017). Positive health and financial practices: Does budgeting make a difference? Journal of Family \& Consumer Sciences, 109(2), 27-36. 
Preuße, H. (2012). Reference budgets for counselling on how to manage private household finance - requirements and patterns based on international experience. International Journal of Consumer Studies, 36(5), 602-610.

Shefrin, H. M., \& Thaler, R. H. (1988). The behavioral life-cycle hypothesis. Economic Inquiry, 26, 609-643.

Shelton, G. G., \& Hill, O. L. (1995). First-time homebuyers programs as an impetus for change in budget behavior. Financial Counseling and Planning, 6, 83-91.

Thaler, R. H. (1985). Mental accounting and consumer choice. Marketing Science, 4(3), 199-214.

Thaler, R. H. (1999). Mental accounting matters. Journal of Behavioral Decision Making, 12(3), $183-206$.

Van Rooij, M., Lusardi, A., \& Alessie, R. (2011). Financial literacy and stock market participation. Journal of Financial Economics, 101(2), 449-472.

Xiao, J. J. (2016). Consumer financial capability. In J. J. Xiao (ed.). (2 ${ }^{\text {nd }}$ ed.). Handbook of consumer finance research (pp. 3-18). New York: Springer.

Xiao, J. J., \& Anderson, J. G. (1997). Hierarchical financial needs reflected by household financial asset shares. Journal of Family and Economic Issues, 18(4), 333-356.

Xiao, J. J., \& Noring, F. E. (1994). Perceived saving motives and hierarchical financial needs. Financial Counseling and Planning. 5, 25-44.

Xiao, J. J., \& O’Neill, B. (2016). Consumer financial education and financial capability. International Journal of Consumer Studies, 40(6), 712-721.

Xiao, J. J., \& O’Neill, B. (2017). Propensity to plan, financial capability, and financial satisfaction. Working paper.

Xiao, J. J., \& Olson, G. I. (1993). Mental accounting and saving behavior. Home Economics 
Research Journal, 22(1), 92-109.

Xiao, J. J., Chen, C., \& Chen, F. (2014). Consumer financial capability and financial satisfaction. Social Indicators Research, 118(1), 415-432. 
Table 1: Variable Specifications

\begin{tabular}{|c|c|c|}
\hline Variable name & Variable label & Attribute \\
\hline & Financial behavior & \\
\hline $\mathrm{J} 31$ & Budgeting & $\begin{array}{l}\text { The original question "Does your household have a } \\
\text { budget? A household budget is used to decide what } \\
\text { share of your household income will be used for } \\
\text { spending, saving or paying bills." If the respondent's } \\
\text { answer is yes, the variable is recoded to } 1 \text {, otherwise } \\
0 \text {. }\end{array}$ \\
\hline $\mathrm{J} 3$ & Underspending & $\begin{array}{l}\text { The original question "Over the past year, would you } \\
\text { say your household spending was less than, more } \\
\text { than, or about equal to your house hold income?" If } \\
\text { the respondent's answer is less than or about equal to } \\
\text { the income, the variable is recoded to } 1 \text {, otherwise } 0 \text {. }\end{array}$ \\
\hline $\mathrm{J} 5$ & Saving for emergency & $\begin{array}{l}\text { The original question "Have you set aside emergency } \\
\text { or rainy day funds that would cover your expenses for } \\
3 \text { months, in case of sickness, job loss, economic } \\
\text { downturn, or other emergencies?" If the respondent's } \\
\text { answer is yes, the variable is recoded to } 1 \text {, otherwise } \\
0 .\end{array}$ \\
\hline $\mathrm{J} 33$ & Long term planning & $\begin{array}{l}\text { The original question "I set long term financial goals } \\
\text { and strive to achieve them" on a scale of } 1 \text {-strongly } \\
\text { disagree to } 7 \text {-strongly agree. If the respondent's } \\
\text { answer is } 5,6 \text { or } 7 \text {, the variable is recoded to } 1 \text {, } \\
\text { otherwise } 0 \text {. }\end{array}$ \\
\hline \multirow[t]{2}{*}{$\mathrm{J} 8$ and $\mathrm{J} 9$} & Calculating retirement needs & $\begin{array}{l}\text { The original question "Have you ever tried to figure } \\
\text { out how much you need to save for retirement?" If the } \\
\text { respondent's answer is yes, the variable is recoded to } \\
1 \text {, otherwise } 0 .\end{array}$ \\
\hline & Other financial capability variables & \\
\hline $\begin{array}{l}\operatorname{Sum}(\mathrm{m} 6, \mathrm{~m} 7 \\
\mathrm{m} 8, \mathrm{~m} 31, \mathrm{~m} 9 \\
\mathrm{~m} 10)\end{array}$ & Objective financial literacy & $\begin{array}{l}0-6 \text {, the sum of correct numbers for financial literacy } \\
\text { questions. The original financial literacy variables } \\
\text { (m6-m10) were recoded to binary variables in which } \\
1=\text { correct answer, } 0=\text { otherwise and then the new } \\
\text { variables were summed to form the score. These } \\
\text { questions asked financial knowledge about interest } \\
(\mathrm{m} 6) \text {, inflation }(\mathrm{m} 7) \text {, bond (m8), time value of money } \\
(\mathrm{m} 31) \text {, mortgage }(\mathrm{m} 9) \text {, and stock (m10). More details } \\
\text { about these questions can be found at Lin et al. } \\
(2016) \text {. }\end{array}$ \\
\hline M4 & Subjective financial literacy & $\begin{array}{l}\text { The question is "On a scale from } 1 \text { to } 7 \text {, where } 1 \\
\text { means very low and } 7 \text { means very high, how would } \\
\text { you assess your overall financial knowledge?" } 1 \text {-very } \\
\text { low, } 7 \text {-very high. }\end{array}$ \\
\hline \multirow[t]{2}{*}{ M1_1 } & Perceived financial capability & $\begin{array}{l}\text { The question is "I am good at dealing with day-to-day } \\
\text { financial matters, such as checking accounts, credit } \\
\text { and debit cards, and tracking expenses," 1-strongly } \\
\text { disagree, 7-strongly agree. }\end{array}$ \\
\hline & Financial wellbeing & \\
\hline $\mathrm{J} 1$ & Financial satisfaction & $\begin{array}{l}\text { The original question "Overall, thinking of your } \\
\text { assets, debts and savings, how satisfied are you with } \\
\text { your current personal financial condition? Please use a } \\
\text { 10-point scale, where } 1 \text { means 'Not At All Satisfied' } \\
\text { and } 10 \text { means 'Extremely Satisfied."' }\end{array}$ \\
\hline A8 & Income level & The original variable has 8 levels: $1-<\$ 15,000$ to 8 - \\
\hline
\end{tabular}


A3

A4a_new_w

A6

A11

A9

A3Ar_w

A5

B1

B2

C1

$\mathrm{C} 4$

Ea_1

E7

E8

G1

$\mathrm{G} 2$

H1

F1

F2_2

G30

G25
Financial wellbeing

Demographic and financial variables

Being male (vs. female)

Being White

Being married

Having dependent children

Working

Age group

Education level

Have checking

Have saving etc.

Have 401(k)

Have IRA etc.

Own home

Have mortgage

Have home equity loan

Have auto loan

Have medical bill

Have health insurance

Have credit card

Have credit card debt

Have student loan

Have high cost loan
$\$ 150,000$ or more. Recoded to 3 income levels:

$1-0$ to less than $\$ 25,000$

2-At least $\$ 25,000$ but less than $\$ 75,000$

3 -At least $\$ 75,000$ and more

A sum of $Z$ values of income and financial

satisfaction variables.

Recoded, $1=$ male, $0=$ female

Recoded, $1=$ white, $0=$ non white

Recoded, $1=$ married, $0=$ not married

Recoded, $1=$ yes, $0=$ no

Recoded, $1=$ yes, $0=$ no

Recoded to 3 age groups:

$1-18-34$

$2-35-64$

$3-65+$

Recoded to 3 education levels:

1-Did not complete high school; High school graduate - regular high school diploma; High school graduate - GED or alternative credential

2-Some college, no degree; Associate's degree

3-Bachelor's degree; Post graduate degree

Recoded, $1=$ yes, $0=$ no

Recoded, $1=$ yes, $0=$ no

Recoded, $1=$ yes, $0=$ no

Recoded, $1=$ yes, $0=$ no

Recoded, $1=$ yes, $0=$ no

Recoded, $1=$ yes, $0=$ no

Recoded, $1=$ yes, $0=$ no

Recoded, $1=$ yes, $0=$ no

Recoded, $1=$ yes, $0=$ no

Recoded, $1=$ yes, $0=$ no

Recoded, $1=$ yes, $0=$ no

Recoded, $1=$ yes, $0=$ no

Recoded, $1=$ yes, $0=$ no

The respondents are asked if they have used several high cost loans such as auto title loan (G25_1), payday loan (G25_2), pawn shop (G25_4), and rentto-own store (G25_5). If they used at least once to any of these loans, it is coded as 1, 0 otherwise. 
Table 2 Characteristics of Budgeter and Non-budgeter $(\mathbf{N}=27,564)$

\begin{tabular}{|c|c|c|c|}
\hline & & Non-Budgeter & Budgeter \\
\hline Total & & $43.8 \%$ & $56.2 \%$ \\
\hline \multirow[t]{2}{*}{ Gender } & female & $42.5 \%$ & $57.5 \%$ \\
\hline & male & $45.4 \%$ & $54.6 \%$ \\
\hline \multirow[t]{2}{*}{ Race } & nonwhite & $41.3 \%$ & $58.7 \%$ \\
\hline & white & $44.7 \%$ & $55.3 \%$ \\
\hline \multirow[t]{2}{*}{ Marital status } & not married & $46.7 \%$ & $53.3 \%$ \\
\hline & married & $41.9 \%$ & $58.1 \%$ \\
\hline \multirow{2}{*}{$\begin{array}{l}\text { Have dependent } \\
\text { children }\end{array}$} & no & $47.4 \%$ & $52.6 \%$ \\
\hline & yes & $37.5 \%$ & $62.5 \%$ \\
\hline \multirow[t]{2}{*}{ Working } & no & $44.8 \%$ & $55.2 \%$ \\
\hline & yes & $43.0 \%$ & $57.0 \%$ \\
\hline \multirow[t]{3}{*}{ Age } & $18-34$ & $39.7 \%$ & $60.3 \%$ \\
\hline & $35-64$ & $44.1 \%$ & $55.9 \%$ \\
\hline & 65 or older & $49.3 \%$ & $50.7 \%$ \\
\hline \multirow[t]{3}{*}{ Education } & High school & $46.9 \%$ & $53.1 \%$ \\
\hline & Some college & $42.6 \%$ & $57.4 \%$ \\
\hline & $\begin{array}{l}\text { 4-year college } \\
\text { degree or higher }\end{array}$ & $42.9 \%$ & $57.1 \%$ \\
\hline \multirow[t]{3}{*}{ Income } & $0-\$ 24999$ & $45.8 \%$ & $54.2 \%$ \\
\hline & $\$ 25000-\$ 74999$ & $42.1 \%$ & $57.9 \%$ \\
\hline & $\$ 75000$ or higher & $44.8 \%$ & $55.2 \%$ \\
\hline \multirow[t]{2}{*}{ Have checking } & no & $53.4 \%$ & $46.6 \%$ \\
\hline & yes & $42.9 \%$ & $57.1 \%$ \\
\hline \multirow[t]{2}{*}{ Have saving } & no & $50.4 \%$ & $49.6 \%$ \\
\hline & yes & $41.8 \%$ & $58.2 \%$ \\
\hline \multirow[t]{2}{*}{ Have 401(k) } & no & $46.3 \%$ & $53.7 \%$ \\
\hline & yes & $41.8 \%$ & $58.2 \%$ \\
\hline \multirow[t]{2}{*}{ Have IRA, etc. } & no & $44.8 \%$ & $55.2 \%$ \\
\hline & yes & $41.7 \%$ & $58.3 \%$ \\
\hline
\end{tabular}




\begin{tabular}{|c|c|c|c|}
\hline \multirow[t]{2}{*}{ Own home } & no & $45.2 \%$ & $54.8 \%$ \\
\hline & yes & $42.9 \%$ & $57.1 \%$ \\
\hline \multirow[t]{2}{*}{ Have mortgage } & no & $46.1 \%$ & $53.9 \%$ \\
\hline & yes & $39.8 \%$ & $60.2 \%$ \\
\hline \multirow{2}{*}{$\begin{array}{l}\text { Have home equity } \\
\text { loan }\end{array}$} & no & $44.4 \%$ & $55.6 \%$ \\
\hline & yes & $38.2 \%$ & $61.8 \%$ \\
\hline \multirow[t]{2}{*}{ Have auto loan } & no & $45.5 \%$ & $54.5 \%$ \\
\hline & Yes & $40.1 \%$ & $59.9 \%$ \\
\hline \multirow{2}{*}{$\begin{array}{l}\text { Have unpaid medical } \\
\text { bill }\end{array}$} & no & $44.4 \%$ & $55.6 \%$ \\
\hline & Yes & $41.1 \%$ & $58.9 \%$ \\
\hline \multirow{2}{*}{$\begin{array}{l}\text { Have health } \\
\text { insurance }\end{array}$} & no & $48.9 \%$ & $51.1 \%$ \\
\hline & yes & $43.1 \%$ & $56.9 \%$ \\
\hline \multirow[t]{2}{*}{ Have credit card } & no & $46.8 \%$ & $53.2 \%$ \\
\hline & yes & $43.0 \%$ & $57.0 \%$ \\
\hline \multirow[t]{2}{*}{ Have credit card debt } & no & $45.5 \%$ & $54.5 \%$ \\
\hline & yes & $40.8 \%$ & $59.2 \%$ \\
\hline \multirow[t]{2}{*}{ Have student loan } & no & $45.1 \%$ & $54.9 \%$ \\
\hline & yes & $40.3 \%$ & $59.7 \%$ \\
\hline \multirow[t]{2}{*}{ Have high cost loan } & no & $45.6 \%$ & $54.4 \%$ \\
\hline & yes & $37.9 \%$ & $62.1 \%$ \\
\hline
\end{tabular}


Table 3 Binary Logistic Regression Results on Being a Budgeter

\begin{tabular}{|c|c|c|c|c|}
\hline & B & SE & $\mathrm{p}$ & OR \\
\hline Male & -.087 & .025 & .001 & .917 \\
\hline White & -.105 & .029 & .000 & .901 \\
\hline Married/cohabiting & .104 & .030 & .001 & 1.109 \\
\hline Have dependent children & .289 & .029 & .000 & 1.335 \\
\hline Working & -.126 & .029 & .000 & .881 \\
\hline Age $35-64$ & -.225 & .031 & .000 & .798 \\
\hline Age 65 and older & -.396 & .045 & .000 & .673 \\
\hline Income $25 \mathrm{k}-75 \mathrm{k}$ & -.092 & .037 & .012 & .912 \\
\hline Income $75 \mathrm{k}$ or more & -.347 & .047 & .000 & .707 \\
\hline Education - some college & .130 & .033 & .000 & 1.139 \\
\hline Education - bachelor degree or higher & .122 & .036 & .001 & 1.130 \\
\hline Have checking & .283 & .051 & .000 & 1.327 \\
\hline Have saving etc. & .287 & .034 & .000 & 1.333 \\
\hline Have $401(\mathrm{k})$ & .061 & .031 & .050 & 1.063 \\
\hline Have IRA etc. & .154 & .031 & .000 & 1.167 \\
\hline Own home & -.003 & .036 & .936 & .997 \\
\hline Have mortgage & .181 & .034 & .000 & 1.199 \\
\hline Have home equity loan & .116 & .045 & .010 & 1.123 \\
\hline Have auto loan & .050 & .029 & .091 & 1.051 \\
\hline Have medical bill & -.028 & .034 & .413 & .972 \\
\hline Have health insurance & .166 & .042 & .000 & 1.180 \\
\hline Have credit card & -.029 & .039 & .457 & .971 \\
\hline Have credit card debt & .076 & .030 & .012 & 1.079 \\
\hline Have student loan & -.034 & .031 & .273 & .966 \\
\hline Have high cost loan & .303 & .032 & .000 & 1.354 \\
\hline Constant & -.347 & .064 & .000 & .707 \\
\hline
\end{tabular}

Notes: reference categories are age under 25 , income under $\$ 25,000$, and education of high school or lower. OR refers to odds ratio. $\mathrm{N}=27564 .-2$ Log likelihood $=36924.792$. Cox \& Snell R Square $=.031$. Nagelkerke R Square $=.041$. Overall percentage of correct predictions $=56.2 \%$. 
Table 4 OLS Regression Results on Financial Wellbeing

\begin{tabular}{|c|c|c|c|c|c|c|c|c|c|}
\hline & $\begin{array}{c}\text { Mode } \\
1 \\
\text { B }\end{array}$ & $\begin{array}{c}1 \\
\text { beta }\end{array}$ & $\mathrm{p}$ & $\begin{array}{c}\text { Model } \\
\text { B }\end{array}$ & $\begin{array}{c}2 \\
\text { beta }\end{array}$ & $\mathrm{p}$ & $\begin{array}{c}\text { Model } \\
\text { B }\end{array}$ & $\begin{array}{c}3 \\
\text { beta }\end{array}$ & $\mathrm{p}$ \\
\hline Constant & -.051 & & .001 & -2.885 & & .000 & -3.212 & & .000 \\
\hline Budgeting & .124 & .037 & .000 & -.284 & -.085 & .000 & -.177 & -.053 & .000 \\
\hline Underspending & & & & .312 & .093 & .000 & .264 & .079 & .000 \\
\hline Saving for emergency & & & & 1.043 & .316 & .000 & .587 & .178 & .000 \\
\hline Planning & & & & .486 & .145 & .000 & .337 & .100 & .000 \\
\hline Calculating retirement needs & & & & .480 & .144 & .000 & .108 & .033 & .000 \\
\hline Objective financial literacy & & & & .071 & .070 & .000 & -.049 & -.049 & .000 \\
\hline Subjective financial literacy & & & & .274 & .198 & .000 & .206 & .149 & .000 \\
\hline Perceived financial capability & & & & .042 & .035 & .000 & .006 & .005 & .250 \\
\hline Male & & & & & & & .193 & .058 & .000 \\
\hline White & & & & & & & -.025 & -.007 & .102 \\
\hline Married/cohabiting & & & & & & & .594 & .175 & .000 \\
\hline Have dependent children & & & & & & & .123 & .036 & .000 \\
\hline Working & & & & & & & .258 & .078 & .000 \\
\hline Age 35-64 & & & & & & & -.058 & -.018 & .001 \\
\hline Age 65 or older & & & & & & & .059 & .014 & .016 \\
\hline Education some college & & & & & & & .061 & .018 & .001 \\
\hline Education bachelor or higher & & & & & & & .356 & .104 & .000 \\
\hline Have checking & & & & & & & -.146 & -.023 & .000 \\
\hline Have saving etc. & & & & & & & .184 & .046 & .000 \\
\hline Have 401(k) & & & & & & & .414 & .124 & .000 \\
\hline Have IRA etc. & & & & & & & .301 & .087 & .000 \\
\hline Own home & & & & & & & .388 & .114 & .000 \\
\hline Have mortgage & & & & & & & .013 & .004 & .478 \\
\hline Have home equity loan & & & & & & & .103 & .018 & .000 \\
\hline Have auto loan & & & & & & & .167 & .047 & .000 \\
\hline Have medical bill & & & & & & & -.332 & -.081 & .000 \\
\hline Have health insurance & & & & & & & .151 & .028 & .000 \\
\hline Have credit card & & & & & & & .465 & .112 & .000 \\
\hline Have credit card debt & & & & & & & -.267 & -.078 & .000 \\
\hline Have student loan & & & & & & & -.125 & -.034 & .000 \\
\hline Have high cost loan & & & & & & & -.016 & -.004 & .343 \\
\hline $\mathrm{R}^{2}$ change & .001 & & & .402 & & & .179 & & \\
\hline F change & 37 & & & 2551 & & & 493 & & \\
\hline $\mathrm{p}$ & .000 & & & .000 & & & .000 & & \\
\hline
\end{tabular}


Figure 1 Comparing Budgeting Behavior with Financial Capability Variables

A. Budgeting and Objective Financial Literacy

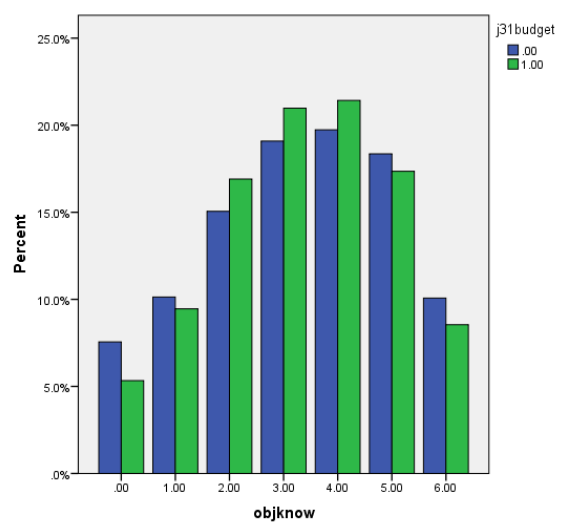

B. Budgeting and Subjective Financial Literacy

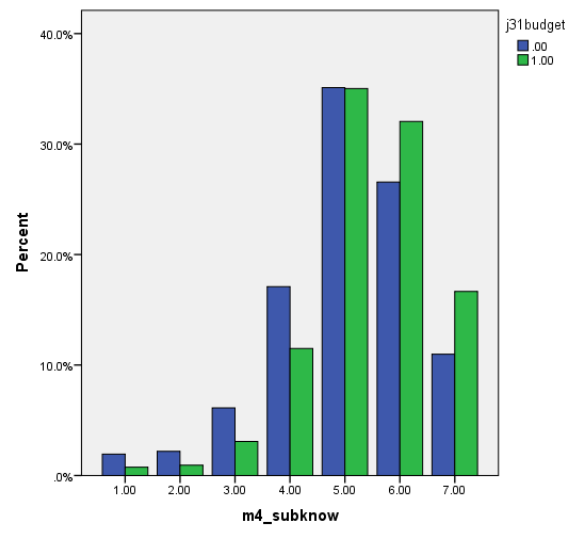

C. Budgeting and Perceived Financial Capability

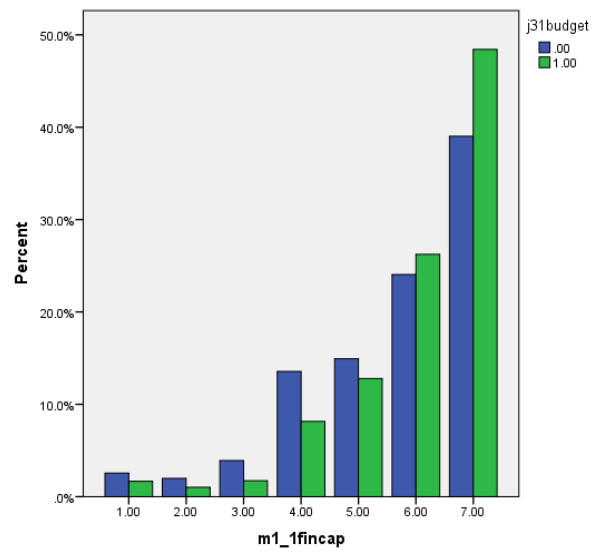


Figure 2 Budgeting and Other Desirable Financial Behavior

A. Budgeting and underspending

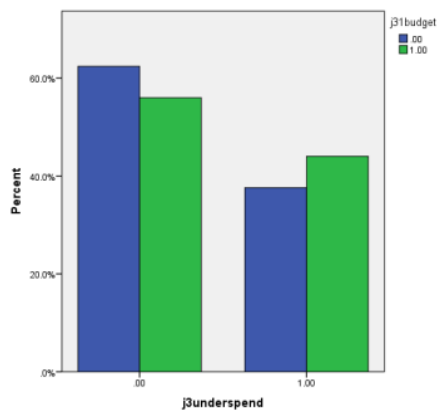

B. Budgeting and Saving for Emergency Fund

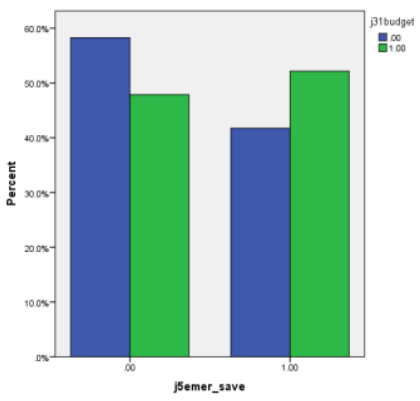

C. Budgeting and Planning

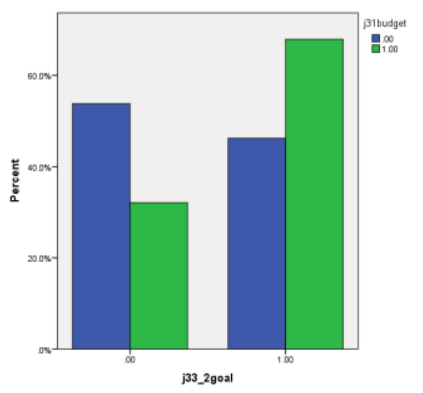

D. Budgeting and Calculating for Retirement Needs

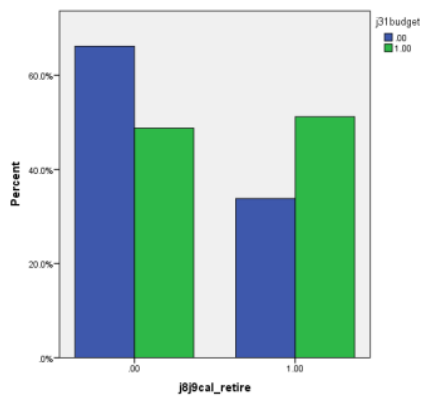


Figure 3 Budgeting and Planning by Financial Wellbeing Groups

A. Budgeting and Planning by Income

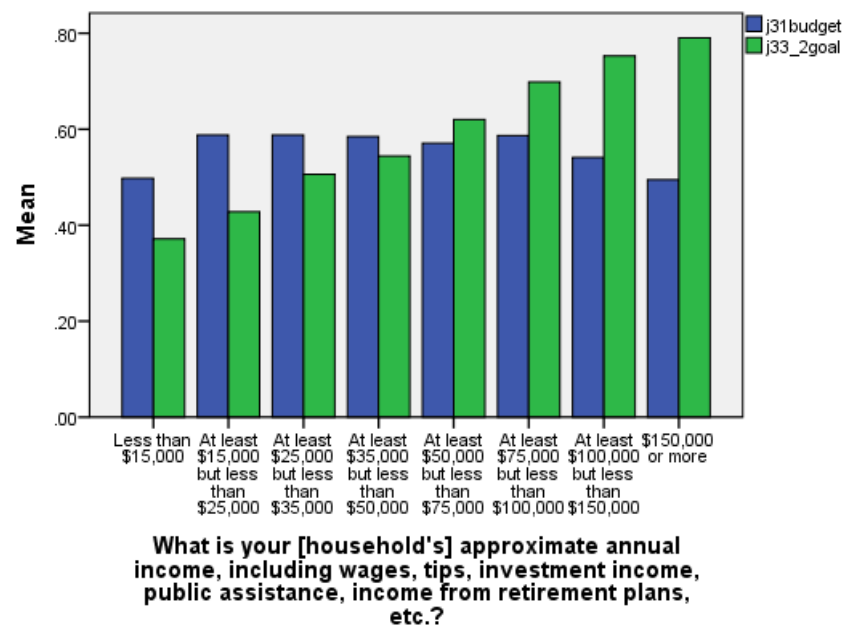

B. Budgeting and Planning by Financial Satisfaction

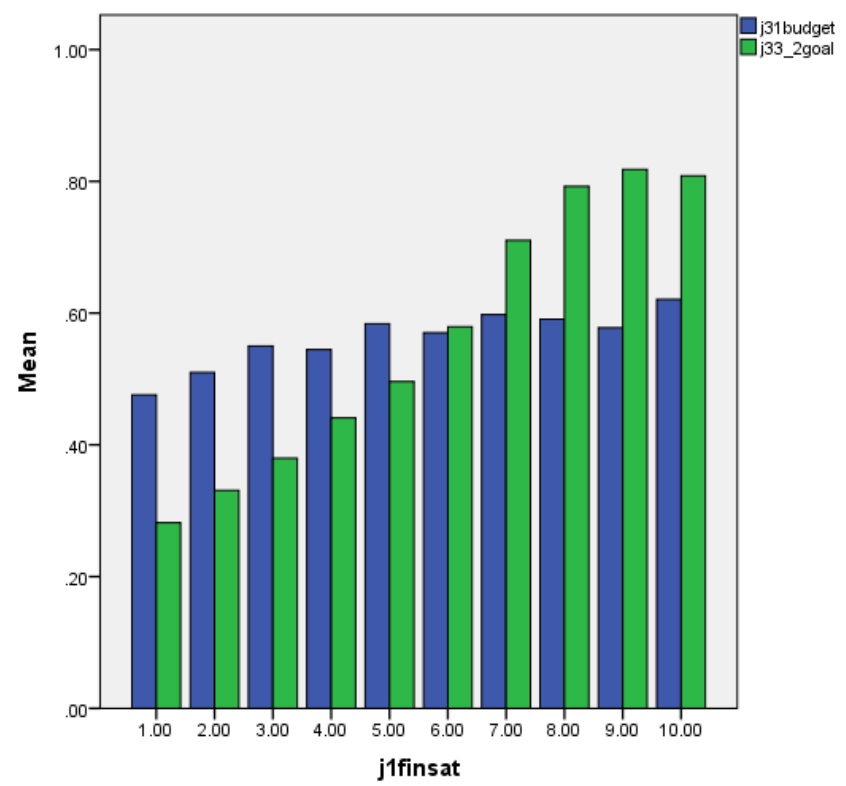


Figure 4 Budgeting and Financial Wellbeing

A. Budgeting and Income

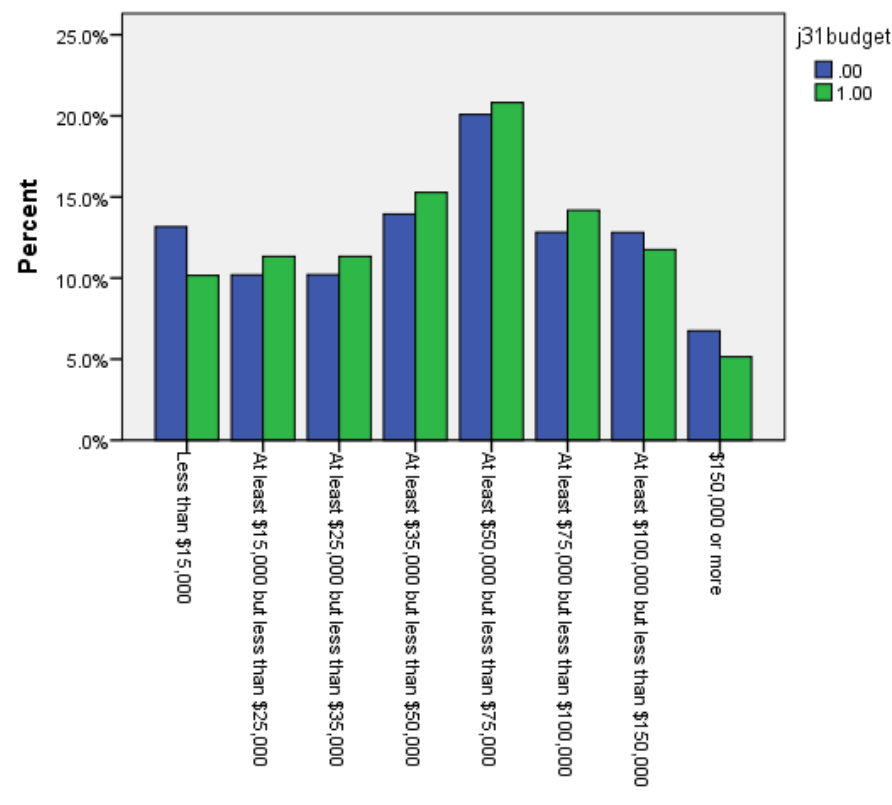

What is your [household's] approximate annual.

B. Budgeting and Financial Satisfaction

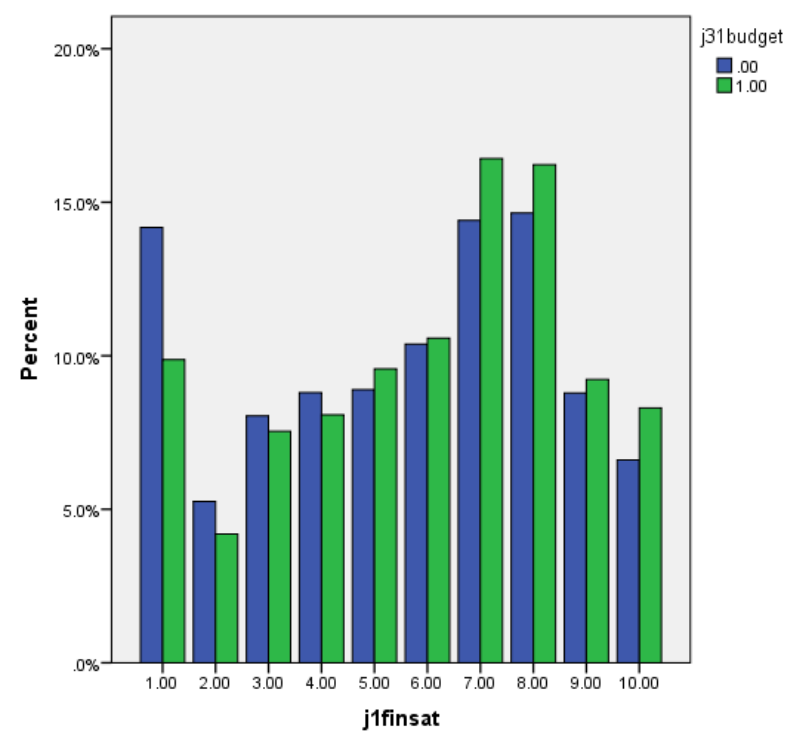

